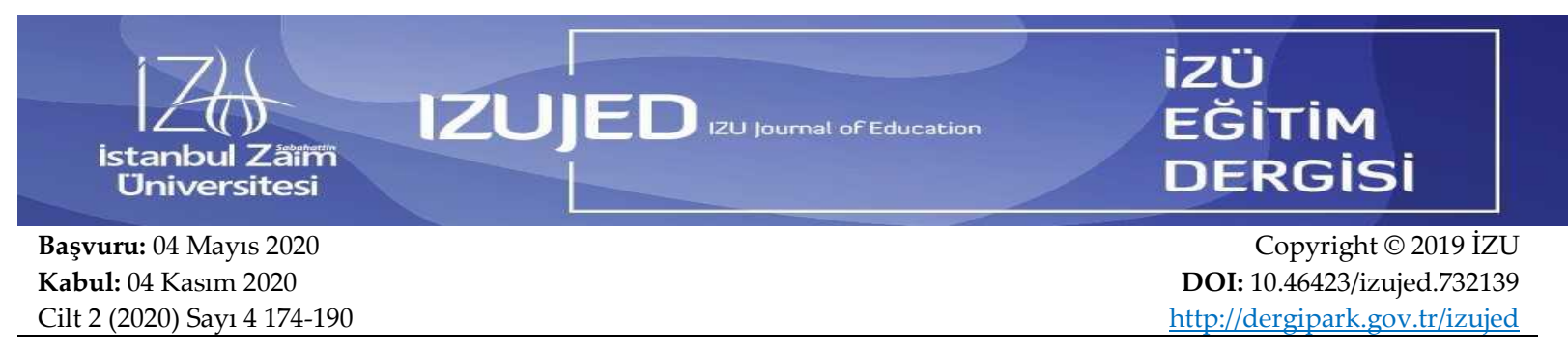

\title{
Okullarda Dedikodu ve Söylenti Durumunun İncelenmesi
}

\author{
Muhammet İbrahim AKYÜREKa
}

\section{Öz}

$\mathrm{Bu}$ araştırmanın amacı, öğretmenlerin cinsiyet, yaş, medeni durum, öğrenim durumu, mesleki kıdem ve okul kademesi değişkenlerine göre okullardaki dedikodu ve söylenti durumunu belirlemektir. Bu araştırma, kesitsel tarama modelindedir. Araştırmanın örneklemini, 2018-2019 eğitim öğretim yılında Ankara ilinde bulunan 20 resmi ilk ve ortaokulda görev yapan toplam 400 öğretmen oluşturmaktadır. Araştırmada; DiFonzo ve Bordia (2000) tarafından geliştirilen "Söylenti yönetimi ölçeği", Eşkin (2010) tarafından geliştirilen "Hemşirelikte dedikodu ve söylentiye ilişkin ölçek" ile Leblebici, Yıldız ve Karasoy (2009)' un "Örgütsel yaşamda dedikodunun araçsallığı ve algılanışı" adlı çalışmalarında geliştirdikleri ölçekler baz alınarak Özşarlak (2016) tarafından geliştirilen "Dedikodu ve söylenti ölçeği" kullanılmıştır. Araştırma sonucunda; öğretmenlerin, dedikodu ve söylenti durumuna ilişkin görüşlerinin katılıyorum düzeyinde olduğu görülmüştür. Bu durum, okullarda dedikodu ve söylenti mekanizmasının aktif ve yaygın bir biçimde işlediğini belirtebilir. Ayrıca öğretmenler tarafından okul içi dedikodu ve söylenti konularının varlığı, okul dışı dedikodu ve söylenti konularından daha fazla olarak görülmüştür. Tüm okul paydaşlarının sağlıklı etkileşim ve iletişimlerinin sosyal etkinliklerle sağlanması yoluyla okullarda dedikodu ve söylenti mekanizmasının olumlu etkilerinden faydalanabilecek okul atmosferleri oluşturulabilir.

Anahtar Kelimeler: Dedikodu, Söylenti, Öğretmen, Okul

\section{Investigation of gossip and rumor in schools}

\section{Abstract}

The aim of this study is to determine the gossip and rumor status in schools according to the variables of teachers' gender, age, marital status, educational status, professional seniority and school level. This research is in cross-sectional survey model. The sample of the study consists of a total of 400 teachers working in 20 public primary and secondary schools in Ankara in the 2018-2019 academic year. In the research; The "Rumor management scale" developed by DiFonzo and Bordia (2000), the "Scale on gossip and rumor in nursing" developed by Eşkin (2010), and the "instrumentality and perception of gossip in organizational life" studies by Leblebici, Yıldız and Karasoy (2009). "Gossip and rumor scale" developed by Özşarlak (2016) based on the scales was used. As a result of the research; It was observed that the teachers' views on the situation of gossip and rumor were at the level of I agree. This situation may indicate that the gossip and rumor mechanism in schools is active and widely functioning. In addition, the existence of in-school gossip and rumor issues was seen by teachers as more than out-of-school gossip and rumor issues. By ensuring healthy interaction and communication of all school stakeholders with social activities, school atmospheres can be created in schools that can benefit from the positive effects of gossip and rumor mechanism.

Keywords: Gossip, Rumor, Teachers, School

a Etimesgut Bilim ve Sanat Merkezi, Ankara, Türkiye. ORCID: 0000-0001-9122-471X E-mail: i_akyurek56@hotmail.com

Atıf: Akyürek, M. İ. (2020). Okullarda dedikodu ve söylenti durumunun incelenmesi. İZü Ĕ̆itim Dergisi, 2(4) 174-190. DOI: 10.46423/izujed.732139 


\section{Extended Abstract}

\section{Introduction}

In educational institutions where the raw material is human and communication is very important, it can be very difficult to deny gossip and rumor channels or try to get rid of these channels completely. In this context, it is important for teachers and school administrators to effectively manage the gossip and rumor process. Seeing the situation of gossip and rumor in schools; it can show some ways how these informal communication channels can be used for effectiveness and efficiency in schools. In this context, taking the opinions of teachers about gossip and rumors in schools may contribute to the process.

\section{Method}

This research is in cross-sectional survey model. The sample of the study consists of a total of 400 teachers working in 20 public primary and secondary schools in Ankara in the 2018-2019 academic year. In the sampling of the teachers, first of all, stratified (proportional) sampling was taken from random sampling methods, and subgroups in the universe (primary and secondary schools) were represented in the sampling in proportion to their weight in the universe, and then the sampling procedure from subpopulations was carried out with random simple neutral element sampling.

In the research; The "Rumor management scale" developed by DiFonzo and Bordia (2000), the "Scale on gossip and rumor in nursing" developed by Esskin (2010), and the "instrumentality and perception of gossip in organizational life" studies by Leblebici, Yıldız and Karasoy (2009). "Gossip and rumor scale" developed by Özşarlak (2016) based on the scales was used.

The measurement tool used in the study was applied to the schools within the scope of the sampling with the scale usage permit obtained from Özşarlak (2016) and the legal permit obtained from the Ankara Provincial Directorate of National Education, in November and December of the 2018-2019 academic year. Apps; It was carried out by the researcher, by interviewing the teachers who participated in the practice in each school in line with the sample list, and giving information about the questionnaire form.

\section{Findings and Discussion}

As a result of the research; It was observed that the teachers' views on the situation of gossip and rumor were at the level of I agree. This situation may indicate that the gossip and rumor mechanism in schools is active and widely functioning.

As a result of the research; Teachers' views on the situation of gossip and rumor at school showed a significant difference according to gender. It has been observed that the views of female teachers on the situation of gossip and rumor at school are higher than those of male teachers. This situation may indicate that female teachers have a 
higher view that the gossip and rumor mechanism in schools is active and widely operating. This may be due to the fact that female teachers are more successful in social networks and attach importance and emphasis to informal relationships and communication.

Research result; It showed that there is a significant difference between the teachers' views on the gossip and rumor situation in school by age. It was determined that the opinions of teachers in the age group 21-30 and 31-40 about the situation of gossip and rumor in the school were higher than the opinions of teachers in the age group 51 and over. This may indicate that young teachers have a higher view that the gossip and rumor mechanism is active and widely operating in schools. This may be due to the fact that young teachers are more successful in social networks and attach importance and emphasis to informal relationships and communication.

As a result of the research; The opinions of the teachers about the gossip and rumor situation in the school did not differ significantly according to the marital status. Research result; It showed that there was no significant difference between the teachers' opinions about the gossip and rumor situation at school according to the educational level.

Research result; showed that there is a significant difference between teachers' views on the situation of gossip and rumor at school, according to professional seniority. It was determined that the opinions of the teachers in the 6-10 years professional seniority group on the situation of gossip and rumor in the school were higher than the opinions of the teachers in the seniority group of 21 or more years. This may indicate that teachers at the beginning of their professional life have a higher view that the gossip and rumor mechanism is active and widely functioning in schools. may be caused.

As a result of the research; The opinions of the teachers about the gossip and rumor situation in the school did not differ significantly according to the school level. By ensuring healthy interaction and communication of all school stakeholders through social activities, school atmospheres can be created in schools that can benefit from the positive effects of gossip and rumor mechanism.

\section{Giriş}

Örgütlerde iletişim, sınırları belirlenmiş ve belirli kurallar doğrultusunda yapılandırılmış formel iletişim kanalları ile kişilerarası ilişkilerden doğan ve herhangi bir yapılandırmaya dâhil olmayan informel iletişim kanalları aracılığıyla gerçekleşir. Dünyanın en eski medyası olarak bilinen dedikodu ve söylenti ise iletişim sürecinin informel boyutlarıdır (Kapferer, 1992). Dedikodu ve söylentiler gündelik hayatta uzak kalınamayan, bazen yakınılan, bazen de kızılan fakat bir biçimde dâhil olunan sosyal ortamlardır. Aslında söylenti ve dedikodu bir iletişim tarzıdır (Solmaz, 2004). İnformel iletişim, özellikle de dedikodu, çalışanlar arasında 
gruplaşmalar yaratır. Gruplaşmalar ekip ruhunun yok olması anlamına gelir ve bu atmosferde de verimlilikten söz edilemez (Eşkin Bacaksız ve Yıldırım, 2013).

Söylenti, kişiler arası informel iletişim ile yayılan ve doğruluğundan şüphe duyulan, kaynağ belirsiz bilgileri içermektedir. Örgüt ortamında söylentiler, genellikle belirsizlik ve değişim zamanlarında ağızdan ağıza yayılan, ilgi çekici, doğrulanma imkânı olmayan bilgilerdir (DiFonzo, Bordia ve Rosnow, 1994). Söylenti ile yayılan bilgiler güncel ya da ilgi çeken konularla ilgili, insanların inanmak istedikleri bilgilerden oluşmaktadır (Knapp, 1944; DiFonzo ve Bordia, 1997). Söylentilerin temel özelliklerini üç başlık altında özetlemek olanaklıdır. Birincisi; söylentiler, kaynağı ve yönü belirsiz, somut gerekçelere dayanmayan bilgilerden oluşmaktadır. İkincisi; söylentiler, yayıldığı grubun ortak ilgisine dayanan hususları içermektedir. Söylentilerin son özelliği ise; genellikle güvenilir bilginin olmadığı ya da bilgi eksikliği yaşanan durumlarda yaygınlık göstermeleridir (DiFonzo vd., 1994).

Literatürde söylenti ile beraber ele alınan, benzerlik ve farklılıklarına vurgu yapılarak kullanılan kavram dedikodudur. Bu durumun sebebi, söylenti ve dedikodunun temel seviyedeki benzerlikleri ile bireylerin zihinlerinde ortak çağrışımlar oluşturması biçiminde ifade edilebilir. Dedikodu, arkadaşlar arasındaki günlük ya da boş konuşma (Rosnow, 2001); kötü niyetli bilgilerin, güvenilir bir kaynağa sahip olmayan ya da doğru olmayan bilgilerin yayılması biçiminde olumsuz ifadelerle betimlenebilmektedir (Dodig-Crnkovic ve Anokhina, 2008). Dedikodunun; sosyal (Erol ve Akyüz, 2015), dini ve kültürel (Houmanfer ve Johnson, 2004) açıdan olumsuz bir kavram şeklinde nitelendirilmesine rağmen, örgütsel literatürde hem olumlu hem de olumsuz sonuçlar doğurabilecek bir olgu biçiminde ele alındığ görülmektedir. Bu tanımlarda dedikodu; genellikle, iki ya da daha fazla bireyin, yanlarında bulunmayan birey ya da gruplar hakkında sahip oldukları bilgileri ya da yorumlarını paylaşması biçiminde belirtilmektedir (Kurland ve Pelled, 2000).

Örgüt içerisinde dedikodu davranışı genellikle sözcükler yoluyla aktarılmış olan doğrulanmamış inançları kapsayan içgüdüsel bir davranıştır. Yönetici ve denetçiler, söylentilerin arkasındaki mesajı arayabilirlerse, söylentileri daha sağlıklı değerlendirebilirler. Birtakım söylentiler duyguların sembolik ifadeleridir. Yönetim, örgüt içerisinde söylenti zincirlerini hiçbir zaman kesemese de; yönetim söylentiyi anlayabilir, yönetebilir ve anlamlı bir biçimde kullanabilir (Akande ve Odewale, 1994). Dedikodu, yönetimsel ayrıcalıklarla mücadele edilen ve yönetimin örgütü kontrol etme yeteneğinin zayıflatıldığı bir süreçtir. Yönetim kontrolünün aşınmasının bir sonucu olarak çalışanların kendi aralarında oluşturdukları alt kültürler, dedikodu aracılığıyla bir derece özerklik kazanma olanağı bulurlar (Noon ve Delbridge, 1993). Örgüt yöneticileri dedikodu ve söylentiyi tamamen ortadan kaldıramazlar. Ama yapmaları gereken; yayılım ve etkisini azaltıp dedikodunun olumsuz sonuçlarını en aza indirgemektir (Robbins ve Judge, 2014).

Söylenti ve dedikodu aracılığıyla aktarılan bilgilerin güvenilir olmaması, kişiler arası ilişkilere zarar verebilmesi ve bireyleri yanlış yönlendirebilmesi gibi sebepler genellikle bu informel iletişim türlerinin olumsuz bir biçimde algılanmasına yol açmaktadır. Ancak literatürde söylenti ve dedikoduların hem olumsuz hem de olumlu olabileceği sıklıkla vurgulanmaktadır (Michelson ve Mouly, 2002). Örgüt ortamında söylenti ve dedikoduya yönelik olumsuz yaklaşımlar; bu iletişim biçimlerinin zamanın boşa harcanmasına, bireysel ve örgütsel imaja zarar vermesine, moral düzeyinin düşmesine, yanlış bilgilerin yayılmasına, olumsuz fikirlerin oluşmasına ve verimliliğin azalmasına yol açtıklarını vurgulamaktadır (Michelson ve Mouly, 
2004). Olumsuz söylenti ve dedikodular birey, grup ya da örgüt için yıkıcı sonuçlara sebep olabilmekte, çalışanlar arasında güven duygusunun azalmasına, şeffaflık ya da dürüstlük gibi etik değerlerin lekelenmesine yol açabilmektedir. Bu olumsuz sonuçlar, çalışanların moral ve motivasyonunu düşürmekte, kişiler arası ilişkilerdeki saygının azalmasına sebep olmaktadır (De Gouveia, Vauren ve Crafford, 2005). Söylenti ve dedikodunun birtakım olumsuz sonuçları yanında, örgütlerde verimlilik ve etkililiğin sağlanmasına dönük olarak da kullanılabileceği ifade edilebilir.

Söylenti ve dedikodular, yöneticilerce örgütü bağlayan yenilik ve değişimler ile örgütsel amaç ve beklentilerin örgütün her kademesine yayılmasını sağlamada kullanılabilecek bir araçtır. Söylenti ve dedikoduların böyle kullanımı ile çalışanların örgütsel süreçler hakkında görüş geliştirmeleri ve örgüt politikalarını anlamlandırmaları daha kolay olabilecektir (Mishra, 1990). Söylenti ve dedikodular, örgütün iç çevresi hakkında yöneticilere gerekli bilgileri sağlayarak, öncelikle ilgilenilmesi gereken durumların neler olduğu hususunda bir erken uyarı sistemi olarak da işlev görebilmektedir (Michelson, Van

Iterson ve Waddington, 2010). Kurland ve Pelled (2000)'in dedikodu ve güç arasındaki ilişkiye vurgu yapan modelinden yola çıkarak söylenti ve dedikoduyu kontrol altında tutan bir yöneticinin, örgütte sahip olduğu kontrol ve gücün daha fazla olacağı söylenebilir. Ayrıca örgütteki söylenti ve dedikodu gibi informel ağlar; yöneticilerin, örgütün farklı seviye ve birimlerindeki koalisyonları belirlemesine, değişime direnci önceden anlamasına ve farklı yönetsel uygulama ve örgütsel değişimlere yönelik desteği belirleyip bunlara ulaşmasına yardımcı olabilmektedir (Michelson, vd., 2010). Bu kapsamda dedikodu ve söylentilerin etkili bir biçimde yönetilebilme durumları öğrenilerek ve kazanılarak informel iletişimin avantajlarından yararlanılabilir. Bu informel iletişim kanallarının etkili olduğu bir örgüt de eğitim kurumları ve içerisindeki eğitim paydaşlarıdır (öğretmen, okul yöneticileri, veliler gibi).

Ham maddesi insan olan ve iletişimin çok önemli olduğu eğitim kurumlarında, dedikodu ve söylenti kanallarını yadsımak veya bu kanallardan tamamen kurtulmaya çalışmak çok zor olabilmektedir. Bu bağlamda öncelikle öğretmen ve okul yöneticilerin dedikodu ve söylenti sürecini etkili yürütebilmeleri önemlidir. Okullarda dedikodu ve söylenti durumunu görmek; bu informel iletişim kanallarının okullarda etkililik ve verimlilik doğrultusunda nasıl kullanılabileceğine dair birtakım yollar gösterebilir. Bu kapsamda öğretmenlerin okullardaki dedikodu ve söylentiye ilişkin görüşlerinin alınması süreç açısından katkı sağlayabilecektir.

\section{Araştırmanın Amacı}

Bu araştırmanın amacı, öğretmenlerin cinsiyet, yaş, medeni durum, öğrenim durumu, mesleki kıdem ve okul kademesi değişkenlerine göre okullardaki dedikodu ve söylenti durumunu belirlemektir. Bu amaç doğrultusunda aşağıdaki sorulara cevap aranacaktır:

Öğretmen görüşlerine göre;

1. Öğgretmenlerin okullardaki dedikodu ve söylenti durumu ne düzeydedir?

2. Öğretmenlerin okullardaki dedikodu ve söylenti durumu, cinsiyete göre farklılık göstermekte midir?

3. Öğretmenlerin okullardaki dedikodu ve söylenti durumu, yaşa göre farklılık göstermekte midir? 
4. Öğretmenlerin okullardaki dedikodu ve söylenti durumu, medeni duruma göre farklılık göstermekte midir?

5. Öğretmenlerin okullardaki dedikodu ve söylenti durumu, öğrenim durumuna göre farklılık göstermekte midir?

6. Öğretmenlerin okullardaki dedikodu ve söylenti durumu, mesleki kıdeme göre farklılık göstermekte midir?

7. Öğretmenlerin okullardaki dedikodu ve söylenti durumu, okul kademesine göre farklılık göstermekte midir?

\section{Yöntem}

Araştırmanın bu kısmında, araştırmanın modeli, evren ve örneklemine, veri toplama araçlarına, verilerin toplanması ve analizine yer verilmiştir.

\section{Araştırmanın Modeli}

$\mathrm{Bu}$ araştırma, kesitsel tarama modelindedir. Tarama modelinde, araştırmadaki konu veya birey bulunduğu koşullar içerisinde olduğu gibi tasvir edilmeye çalışılır (Karasar, 2015). Bu modele dayalı olarak öğretmenlerin cinsiyet, yaş, medeni durum, öğrenim durumu, mesleki kıdem ve okul kademesi değişkenlerine göre okullardaki dedikodu ve söylenti durumu değerlendirilmiştir.

\section{Evren ve Örneklem}

Araştırmanın örneklemini, 2018-2019 eğitim öğretim yılında Ankara ilinde bulunan 20 resmi ilk ve ortaokulda görev yapan toplam 400 öğretmen oluşturmaktadır. Öğretmenlerin örnekleme alınmasında, öncelikle seçkisiz örnekleme yöntemlerinden tabakalı(oranlı) örnekleme alınarak, evrendeki alt grupların (ilkokul ve ortaokul) evrendeki ağırlıkları oranında örneklemde temsil edilmeleri sağlanmıştır, sonrasında ise alt evrenlerden örnekleme alma işlemi random basit yansız eleman örnekleme ile gerçekleştirilmiştir. Araştırma evrenindeki toplam öğretmen sayısı 33286'dır (MEB, 2018). Araştırma evrenindeki öğretmenlerden toplam 400 'ü örnekleme alınmıştır. Evren ve örneklemde yer alan öğretmen sayılarına tablo 1'de yer verilmiştir.

Tablo 1. Evren ve Örneklemde Yer Alan Öğretmen Sayıları

\begin{tabular}{cccccc}
\hline & Evren & & \multicolumn{3}{c}{ Örneklem } \\
\hline İlkokul & Ortaokul & Toplam & İlkokul & Ortaokul & Toplam \\
\hline 15350 & 17936 & 33286 & 184 & 216 & 400 \\
\hline
\end{tabular}

Araştırmaya katılan öğretmenlerin demografik özelliklerine ilişkin bilgilerine tablo 2'de yer verilmiştir.

Tablo 2. Demografik Değişkenlere Göre Frekans ve Yüzde Dağılımları

\begin{tabular}{llll}
\hline & Değişken & $\mathrm{N}$ & $\%$ \\
\hline Cinsiyet & Kadın & 302 & 75.5 \\
& Erkek & 98 & 24.5 \\
\hline \multirow{2}{*}{ Yaş } & $21-30$ yaş & 70 & 17.5 \\
& $31-40$ yaş & 206 & 51.5 \\
\hline
\end{tabular}




\begin{tabular}{llll}
\hline & 41-50 yaş & 84 & 21 \\
& 51 ve üzeri yaş & 40 & 10 \\
\hline Medeni & Evli & 337 & 84.3 \\
durum & Bekâr & 63 & 15.8 \\
\hline Öğrenim & Ön lisans & 19 & 4.8 \\
durumu & Lisans & 343 & 85.8 \\
& Lisansüstü & 38 & 9.5 \\
\hline Mesleki & $1-5$ yıl & 62 & 15.5 \\
kıdem & 6-10 y1l & 79 & 19.8 \\
& $11-15$ yıl & 114 & 28.5 \\
& $16-20$ yıl & 72 & 18 \\
& 21 ve daha fazla yıl & 73 & 18.3 \\
\hline Okul & İlkokul & 184 & 46 \\
kademesi & Ortaokul & 216 & 54 \\
\hline & Toplam & 400 & 100 \\
\hline
\end{tabular}

Tablo incelendiğinde; cinsiyet değişkenine göre oran olarak kadınların \%75.5 ile, erkeklere göre daha fazla olduğu görülmektedir. Yaş değişkenine göre en fazla orana sahip grubu \%51.5 ile 31-40 yaş, en az orana sahip grubu ise \%10 ile 51 ve üzeri yaş grubu oluşturmaktadır. Medeni durum değişkenine göre oran olarak evli olanların \%84.3 ile, bekâr olanlara göre daha fazla olduğu görülmektedir. Öğrenim durumu değişkenine göre en fazla orana sahip grubu \%85.8 ile lisans, en az orana sahip grubu ise \%4.8 ile ön lisans grubu oluşturmaktadır. Mesleki kıdem değişkenine göre en fazla orana sahip grubu \%28.5 ile 11-15 yıl, en az orana sahip grubu ise \%18 ile 16-20 yıl oluşturmaktadır. Okul kademesi değişkenine göre oran olarak ortaokulda görevli öğretmenlerin \%54 ile, ilkokulda görevli öğretmenlere göre daha fazla olduğu görülmektedir.

\section{Veri Toplama Araçları}

Araştırmada; DiFonzo ve Bordia (2000) tarafından geliştirilen "Söylenti yönetimi ölçeği", Eşkin (2010) tarafından geliştirilen "Hemşirelikte dedikodu ve söylentiye ilişkin ölçek" ile Leblebici, Yıldız ve Karasoy (2009)' un “Örgütsel yaşamda dedikodunun araçsallığ1 ve algılanışı" adlı çalışmalarında geliştirdikleri ölçekler baz alınarak Özşarlak (2016) tarafından geliştirilen "Dedikodu ve söylenti ölçeği" kullanılmıştır.

Ölçeğin güvenirliğini test etmek amacıyla; ölçek Likert tipi olduğundan ve tek uygulamadan elde edildiğinden Cronbach Alpha güvenirlik katsayısı $(\alpha)$ hesaplanmıştır. Tablo 3'te görüldügü üzere güvenirlik katsayısı " $\alpha=.77$ " olarak bulunmuştur. Psikolojik bir test için hesaplanan güvenirlik katsayısının .70 ve daha yüksek olması test puanlarının güvenirliği için genel olarak yeterli görülmektedir (Büyüköztürk, 2013). Dedikodu ve söylenti ölçeği güvenirlik analizine tablo 3 'te yer verilmiştir.

\section{Tablo 3. Dedikodu ve Söylenti Ölçeği Güvenirlik Analizi}

$\frac{\text { Alfa Katsayısı }}{\text { Gözlem Sayısı }}$


Hiç (1.00-1.79)

Nadiren (1.80-2.59)

Ara sira (2.60-3.39)

Sik sik (3.40-4.19)

Her zaman (4.20-5.00)

- "Dedikodu ve söylenti ölçeği" derecelendirme aralıkları:

Hiç katılmıyorum (1.00-1.79)

Katılmiyorum (1.80-2.59)

Kararsizım (2.60-3.39)

Kat1liyorum (3.40-4.19)

Tamamen katıllyorum (4.20-5.00)

\section{Verilerin Toplanması ve Analizi}

Araştırmada kullanılan ölçme aracı, Özşarlak (2016)' tan alınan ölçek kullanım izni ve Ankara İl Millî Eğitim Müdürlügü’nden alınan yasal izin belgesi ile örneklem kapsamındaki okullara gidilerek, 2018-2019 eğitim öğretim yılı Kasım ve Aralık ayları içerisinde uygulanmıştır. Uygulamalar; araştırmacı tarafından, örneklem listesi doğrultusunda her bir okulda uygulamaya katılan öğretmenlerle görüşülerek, anket formu hakkında bilgi verilmesi ile birlikte gerçekleştirilmiştir.

Büyük gruplar üzerinden toplanan verilerin, normal dağılıma yakın dağılım gösterdikleri kabul edilir ve buna göre parametrik istatistikler seçilebilir. Dağılımın normal dağılımdan aşırı sapma göstermediği şeklinde bir varsayımı ileri sürmek için öngörülen örneklem büyüklüğ̈̈ genellikle 30 ve daha büyük olarak gösterilmektedir. Ancak sosyal bilimlerde pek çok araştırmalar, özellikle de deneysel araştırmalar, daha küçük gruplar üzerinde yapılmaktadır. Literatürde, alt grupların her birinin büyüklüklerinin 15 ve daha yüksek olması durumunda parametrik bir istatistiğin kullanılmasının, analizde hesaplanacak " $\mathrm{p}$ " anlamlılık düzeyinde önemli bir sapmaya yol açmadığına ilişkin incelemelere rastlanmaktadır (Büyüköztürk, 2013). $\mathrm{Bu}$ kapsamda verilerin çözümlenmesi doğrultusunda, öncelikle frekans ve yüzde analizleri yapılmıştır. Ayrıca iki alt kategorili değişkenlerde, bağımsız (ilişkisiz) örneklemler için t-testi; üç ya da daha fazla alt kategorili değişkenlerde ise, tek yönlü varyans analizi (ANOVA) uygulanmıştır. Bulguların yorumlanmasında, anlamlılık değeri $\mathrm{p}<.05$ olarak kabul edilmiştir.

\section{Bulgular ve Yorum}

Araştırmanın birinci alt problemi kapsamında; öğretmenlerin okuldaki dedikodu ve söylenti durumu incelenmiştir. Bu amaçla yapılan analizlerde aritmetik ortalama ve standart sapma tekniklerinden yararlanılmıştır. Aşağıdaki tabloda, öğretmenlerin okuldaki dedikodu ve söylenti durumuna ilişkin betimsel istatistiklere yer verilmiştir.

Tablo 4. Öğretmenlerin Okuldaki Dedikodu ve Söylenti Durumuna İlişkin Betimsel İstatistikler

\begin{tabular}{lllll}
\hline Boyutlar & $N$ & $\bar{x}$ & $S S$ \\
\hline
\end{tabular}




\begin{tabular}{llll}
\hline Okul içi dedikodu ve söylenti konularının sıklık dereceleri & 400 & 2.67 & .82 \\
Okul dışı dedikodu ve söylenti konularının sıklık dereceleri & 400 & 2.38 & .72 \\
Dedikodu ve söylentilerin nedenleri & 400 & 3.53 & .65 \\
Dedikodu ve söylentilerin etkileri & 400 & 3.37 & .49 \\
Dedikodu ve söylentilerin etki ve nedenleri (Genel) & 400 & 3.44 & .47 \\
\hline
\end{tabular}

Tablo incelendiğinde; öğretmenlerin, dedikodu ve söylenti durumuna ilişkin görüşlerinin katılıyorum düzeyinde ( $\bar{x}=3.44)$ olduğu görülmektedir. Ayrıca boyutlar bazında dedikodu ve söylenti durumuna ilişkin görüşleri incelendiğinde ise; dedikodu ve söylentilerin nedenleri ( $\bar{x}=3.53)$ "katıllyorum" ve dedikodu ve söylentilerin etkilerinin $(\bar{x}=3.37)$ ise "kararsızım" düzeyinde olduğu görülmektedir.

Ayrıca öğretmenler tarafından okul içi (okul imajı, öğrenci tatmini, eğitim kalitesi ve "temel eğitim -okul öncesi, ilkokul ve ortaokul-" sistemi ve mevzuat ile ilgili) dedikodu ve söylenti konularının varlığı ( $\bar{x}=2.67$-nadiren), okul dışı (yönetim, ücretler, öğretmenlerin özel hayatı, özlük değişikliği -terfi, atama vb.- ve soruşturma, ceza vb. hakkında) dedikodu ve söylenti konularından ( $\bar{x}=2.38$-katılmıyorum) daha fazla olarak görülmektedir.

Araştırmanın ikinci alt problemi kapsamında; cinsiyet değişkenine göre öğretmenlerin okuldaki dedikodu ve söylenti durumu incelenmiştir. Cinsiyet değişkenine göre, öğretmenlerin okuldaki dedikodu ve söylenti durumuna ilişkin t-testi sonuçlarına aşağıdaki tabloda yer verilmiştir.

Tablo 5. Cinsiyet Değişkenine Göre Öğretmenlerin Okuldaki Dedikodu ve Söylenti Durumuna İlişkin T-Testi Sonuçları

\begin{tabular}{llllllll}
\hline Boyutlar & Cinsiyet & $N$ & $\bar{x}$ & $S$ & sd & $t$ & $p$ \\
\hline Dedikodu ve söylentilerin & Kadın & 302 & 3.59 & .56 & 398 & 2.85 & $.00^{*}$ \\
nedenleri & Erkek & 98 & 3.37 & .86 & & & \\
\hline Dedikodu ve söylentilerin & Kadın & 302 & 3.40 & .36 & 398 & 2.53 & $.01^{*}$ \\
etkileri & Erkek & 98 & 3.26 & .75 & & & \\
\hline Dedikodu ve söylentilerin & Kadın & 302 & 3.48 & .35 & 398 & 3.20 & $.00^{*}$ \\
etki ve nedenleri (Genel) & Erkek & 98 & 3.31 & .71 & & & \\
\hline
\end{tabular}

" $p<.05$

Tablo incelendiğinde; öğretmenlerin okuldaki dedikodu ve söylenti durumuna ilişkin görüşleri, cinsiyete göre anlamlı bir farklılık göstermektedir, $t(398)=2.85, p<.05$. Kadın öğretmenlerin okuldaki dedikodu ve söylenti durumuna ilişkin görüşlerinin $(\bar{x}=3.48$ katılıyorum), erkek öğretmenlerin görüşlerinden ( $\bar{x}=3.31$-kararsızım) daha yüksek olduğu görülmektedir. Araştırma bulgusu, öğretmenlerin okuldaki dedikodu ve söylenti durumu ile cinsiyet arasında anlamlı bir ilişkinin olduğu şeklinde de yorumlanabilir.

Tüm boyutlarda; öğretmenlerin okuldaki dedikodu ve söylentilerin neden ve etkilerine ilişkin görüşleri, cinsiyete göre anlamlı bir farklılık göstermektedir, $p<.05$. Kadın öğretmenlerin dedikodu ve söylenti neden ve etki boyutlarına ilişkin görüşlerinin (katıllyorum), erkek öğretmenlerin görüşlerinden (kararsızım) daha yüksek olduğu görülmektedir.

Araştırmanın üçüncü alt problemi kapsamında; yaş değişkenine göre öğretmenlerin okuldaki dedikodu ve söylenti durumu incelenmiştir. Yaş değişkenine göre, öğretmenlerin okuldaki 
dedikodu ve söylenti durumuna ilişkin tek yönlü varyans analizi (ANOVA) sonuçlarına aşağıdaki tabloda yer verilmiştir.

Tablo 6. Yaş Değişkenine Göre Öğretmenlerin Okuldaki Dedikodu ve Söylenti Durumuna İlişkin Tek Yönlü Varyans Analizi (ANOVA) Sonuçları

\begin{tabular}{llllllll}
\hline Boyutlar & Yaş & $N$ & $\bar{x}$ & $S S$ & $F$ & $p$ & Anlaml Fark \\
\hline Dedikodu ve & 21-30 yaş & 70 & 3.58 & .64 & 6.13 & $.00^{*}$ & 31-40/51 ve \\
söylentilerin nedenleri & 31-40 yaş & 206 & 3.60 & .57 & & & üzeri \\
& 41-50 yaş & 84 & 3.51 & .54 & & & \\
& 51 ve üzeri yaş & 40 & 3.13 & 1.04 & & & \\
\hline Dedikodu ve & 21-30 yaş & 70 & 3.40 & .57 & 2.20 & .08 & --- \\
söylentilerin etkileri & 31-40 yaş & 206 & 3.41 & .39 & & & \\
& 41-50 yaş & 84 & 3.29 & .45 & & & \\
& 51 ve üzeri yaş & 40 & 3.24 & .77 & & & \\
\hline Dedikodu ve & 21-30 yaş & 70 & 3.48 & .54 & 5.13 & $.00^{*}$ & 21-30/51 ve \\
söylentilerin etki ve & 31-40 yaş & 206 & 3.50 & .41 & & & üzeri, 31-40/51 \\
nedenleri (Genel) & 41-50 yaş & 84 & 3.38 & .32 & & & ve üzeri \\
& 51 ve üzeri yaş & 40 & 3.20 & .76 & & & \\
\hline
\end{tabular}

${ }^{*} p<.05$

Tablodaki analiz sonuçları; öğretmenlerin okuldaki dedikodu ve söylenti durumuna ilişkin görüşleri arasında yaşa göre anlamlı bir fark olduğunu göstermektedir, $F=5.13, p<.05$. Başka bir deyişle, öğretmenlerin okuldaki dedikodu ve söylenti durumuna ilişkin görüşleri, yaşa bağlı olarak anlamlı bir şekilde değişmektedir. Yaş grupları arası farkların hangi gruplar arasında olduğunu bulmak amaciyla yapılan Scheffe testinin sonuçlarına göre; 21-30 ve 31-40 yaş grubundaki öğretmenlerin okuldaki dedikodu ve söylenti durumuna ilişkin (katılıyorum düzeyindeki) görüşlerinin, 51 ve üzeri yaş grubundaki öğretmenlerin (kararsızım düzeyindeki) görüşlerinden daha yüksek olduğu belirlenmiştir.

Tablodaki, boyutlar bazında analiz sonuçları; öğretmenlerin okuldaki dedikodu ve söylentilerin nedenleri boyutuna ilişkin görüşleri arasında yaşa göre anlamlı bir fark olduğunu göstermektedir, $F=6.13, p<.05$. Başka bir deyişle, öğretmenlerin okuldaki dedikodu ve söylentilerin nedenleri boyutuna ilişkin görüşleri, yaşa bağlı olarak anlamlı bir şekilde değişmektedir. Yaş grupları arası farkların hangi gruplar arasında olduğunu bulmak amacıyla yapılan Dunnets's C testinin sonuçlarına göre; 31-40 yaş grubundaki öğretmenlerin okuldaki dedikodu ve söylentilerin nedenleri boyutuna ilişkin (katılıyorum düzeyindeki) görüşlerinin, 51 ve üzeri yaş grubundaki öğretmenlerin (kararsızım düzeyindeki) görüşlerinden daha yüksek olduğu belirlenmiştir.

Ayrıca; öğretmenlerin okuldaki dedikodu ve söylentilerin etkileri boyutuna ilişkin görüşleri arasında yaşa göre anlamlı bir fark olmadığını göstermektedir, $F=2.20, p>.05$. Başka bir deyişle, öğretmenlerin okuldaki dedikodu ve söylentilerin etkileri boyutuna ilişkin görüşleri, yaşa bağlı olarak anlamlı bir şekilde değişmemektedir.

Araştırmanın dördüncü alt problemi kapsamında; medeni durum değişkenine göre öğretmenlerin okuldaki dedikodu ve söylenti durumu incelenmiştir. Medeni durum değişkenine göre, öğretmenlerin okuldaki dedikodu ve söylenti durumuna ilişkin t-testi sonuçlarına aşağıdaki tabloda yer verilmiştir. 
Tablo 7. Medeni Durum Değişkenine Göre Öğretmenlerin Okuldaki Dedikodu ve Söylenti Durumuna İlişkin T-Testi Sonuçları

\begin{tabular}{llllllll}
\hline Boyutlar & $\begin{array}{l}\text { Medeni } \\
\text { durum }\end{array}$ & $N$ & $\bar{x}$ & $S$ & sd & $t$ & $p$ \\
\hline Dedikodu ve söylentilerin & Evli & 337 & 3.52 & .65 & 398 & .59 & .55 \\
& Bekâr & 63 & 3.58 & .68 & & & \\
\hline nedenleri & Evli & 337 & 3.35 & .49 & 398 & 1.74 & .08 \\
Dedikodu ve söylentilerin & Bekâr & 63 & 3.46 & .45 & & & \\
\hline Dedileri & Evli & 337 & 3.42 & .47 & 398 & 1.37 & .17 \\
etki ve nedu ve söylentilerin & Bekâr & 63 & 3.51 & .46 & & & \\
\hline
\end{tabular}

${ }^{*} p<.05$

Tablo incelendiğinde; öğretmenlerin okuldaki dedikodu ve söylenti durumuna ilişkin görüşleri, medeni duruma göre anlamlı bir farklılık göstermemektedir, $t(398)=1.37, p>$.05. Evli ve bekâr öğretmenlerin okuldaki dedikodu ve söylenti durumuna ilişkin görüşlerinin katılıyorum düzeyinde olduğu görülmektedir. Araştırma bulgusu, öğretmenlerin okuldaki dedikodu ve söylenti durumu ile medeni durum arasında anlamlı bir ilişkinin olmadığ şeklinde de yorumlanabilir.

Tüm boyutlarda; öğretmenlerin okuldaki dedikodu ve söylentilerin neden [t(398)=.59] ve etkileri $[t(398)=1.74]$ boyutlarına ilişkin görüşleri, medeni duruma göre anlamlı bir farklılık göstermemektedir, $p>.05$.

Araştırmanın beşinci alt problemi kapsamında; öğrenim durumu değişkenine göre öğretmenlerin okuldaki dedikodu ve söylenti durumu incelenmiştir. Öğrenim durumu değişkenine göre, öğretmenlerin okuldaki dedikodu ve söylenti durumuna ilişkin tek yönlü varyans analizi (ANOVA) sonuçlarına aşağıdaki tabloda yer verilmiştir.

Tablo 8. Öğrenim Durumu Değişkenine Göre Öğretmenlerin Okuldaki Dedikodu ve Söylenti Durumuna İlişkin Tek Yönlü Varyans Analizi (ANOVA) Sonuçları

\begin{tabular}{llllllll}
\hline Boyutlar & $\begin{array}{l}\text { Öğrenim } \\
\text { durumu }\end{array}$ & $N$ & $\bar{x}$ & $S S$ & $F$ & $p$ & Anlaml Fark \\
\hline Dedikodu ve & Ön lisans & 19 & 3,45 &, 73 & 1.27 & .28 & --- \\
söylentilerin & Lisans & 343 & 3,52 &, 66 & & & \\
nedenleri & Lisansüstü & 38 & 3,69 &, 54 & & & \\
\hline Dedikodu ve & Ön lisans & 19 & 3,43 &, 27 & .26 & .77 & -- \\
söylentilerin & Lisans & 343 & 3,36 &, 51 & & & \\
etkileri & Lisansüstü & 38 & 3,39 &, 34 & & & \\
\hline Dedikodu ve & Ön lisans & 19 & 3,44 &, 25 & .61 & .54 & -- \\
söylentilerin & Lisans & 343 & 3,43 &, 49 & & & \\
etki ve & Lisansüstü & 38 & 3,52 &, 32 & & & \\
nedenleri & & & & & & & \\
(Genel) & & & & & & &
\end{tabular}

$" p<.05$

Tablodaki analiz sonuçları; öğretmenlerin okuldaki dedikodu ve söylenti durumuna ilişkin görüşleri arasında öğrenim durumuna göre anlamlı bir fark olmadığını göstermektedir, $F=.61$, 
$p>$.05. Başka bir deyişle, öğretmenlerin okuldaki dedikodu ve söylenti durumuna ilişkin görüşleri, öğrenim durumuna bağlı olarak anlamlı bir şekilde değişmemektedir.

Tablodaki, boyutlar bazında analiz sonuçları; öğretmenlerin okuldaki dedikodu ve söylentilerin neden $(F=1.27)$ ve etkileri $(F=.26)$ boyutlarına ilişkin görüşleri arasında öğrenim durumuna göre anlamlı bir fark olmadığını göstermektedir, $p>.05$. Başka bir deyişle, öğretmenlerin okuldaki dedikodu ve söylentilerin neden ve etkileri boyutlarına ilişkin görüşleri, öğrenim durumuna bağlı olarak anlamlı bir şekilde değişmemektedir.

Araştırmanın altıncı alt problemi kapsamında; mesleki kıdem değişkenine göre öğretmenlerin okuldaki dedikodu ve söylenti durumu incelenmiştir. Mesleki kıdem değişkenine göre, öğretmenlerin okuldaki dedikodu ve söylenti durumuna ilişkin tek yönlü varyans analizi (ANOVA) sonuçlarına aşağıdaki tabloda yer verilmiştir.

Tablo 9. Mesleki Kıdem Değişkenine Göre Öğretmenlerin Okuldaki Dedikodu ve Söylenti Durumuna İlişkin Tek Yönlü Varyans Analizi (ANOVA) Sonuçları

\begin{tabular}{|c|c|c|c|c|c|c|c|}
\hline Boyutlar & $\begin{array}{l}\text { Mesleki } \\
\text { kıdem }\end{array}$ & $N$ & $\bar{x}$ & $S S$ & $F$ & $p$ & Anlamlı Fark \\
\hline \multirow{5}{*}{$\begin{array}{l}\text { Dedikodu ve } \\
\text { söylentilerin } \\
\text { nedenleri }\end{array}$} & $1-5$ y1l & 62 & 3.64 & .60 & \multirow[t]{5}{*}{2.58} & \multirow[t]{5}{*}{.06} & \multirow[t]{5}{*}{---} \\
\hline & 6-10 y1l & 79 & 3.69 & .46 & & & \\
\hline & $11-15$ yil & 114 & 3.47 & .64 & & & \\
\hline & $16-20$ yil & 72 & 3.45 & .70 & & & \\
\hline & $\begin{array}{l}21 \text { ve daha } \\
\text { fazla yıl }\end{array}$ & 73 & 3.43 & .80 & & & \\
\hline \multirow{5}{*}{$\begin{array}{l}\text { Dedikodu ve } \\
\text { söylentilerin } \\
\text { etkileri }\end{array}$} & $1-5$ yıl & 62 & 3.26 & .54 & \multirow[t]{5}{*}{4.61} & \multirow[t]{5}{*}{$.00^{*}$} & \multirow{5}{*}{$\begin{array}{l}\text { 6-10/21 ve daha } \\
\text { fazla }\end{array}$} \\
\hline & 6-10 yıl & 79 & 3.48 & .43 & & & \\
\hline & $11-15$ y1l & 114 & 3.41 & .51 & & & \\
\hline & $16-20 \mathrm{y} 1 \mathrm{l}$ & 72 & 3.43 & .32 & & & \\
\hline & $\begin{array}{l}21 \text { ve daha } \\
\text { fazla y1l }\end{array}$ & 73 & 3.20 & .55 & & & \\
\hline \multirow{5}{*}{$\begin{array}{l}\text { Dedikodu ve } \\
\text { söylentilerin } \\
\text { etki ve } \\
\text { nedenleri } \\
\text { (Genel) }\end{array}$} & $1-5$ yıl & 62 & 3.43 & .42 & \multirow[t]{5}{*}{3.18} & \multirow[t]{5}{*}{$.01^{*}$} & \multirow{5}{*}{$\begin{array}{l}\text { 6-10/21 ve daha } \\
\text { fazla }\end{array}$} \\
\hline & 6-10 yıl & 79 & 3.57 & .38 & & & \\
\hline & $11-15$ yil & 114 & 3.44 & .51 & & & \\
\hline & $16-20$ yıl & 72 & 3.44 & .39 & & & \\
\hline & $\begin{array}{l}21 \text { ve daha } \\
\text { fazla yıl }\end{array}$ & 73 & 3.30 & .57 & & & \\
\hline
\end{tabular}

$" p<.05$

Tablodaki analiz sonuçları; öğretmenlerin okuldaki dedikodu ve söylenti durumuna ilişkin görüşleri arasında mesleki kıdeme göre anlamlı bir fark olduğunu göstermektedir, $F=3.18$, $p<$ .05. Başka bir deyişle, öğretmenlerin okuldaki dedikodu ve söylenti durumuna ilişkin görüşleri, mesleki kıdeme bağlı olarak anlamlı bir şekilde değişmektedir. Mesleki kıdem grupları arası farkların hangi gruplar arasında olduğunu bulmak amacıyla yapılan Scheffe testinin sonuçlarına göre; 6-10 yıl mesleki kıdem grubundaki öğretmenlerin okuldaki dedikodu ve söylenti durumuna ilişkin (katılıyorum düzeyindeki) görüşlerinin, 21 ve daha fazla yıl mesleki kıdem grubundaki öğretmenlerin (kararsızım düzeyindeki) görüşlerinden daha yüksek olduğu belirlenmiştir.

Tablodaki, boyutlar bazında analiz sonuçları; öğretmenlerin okuldaki dedikodu ve söylentilerin etkileri boyutuna ilişkin görüşleri arasında mesleki kıdeme göre anlamlı bir fark 
olduğunu göstermektedir, $F=4.61, p<.05$. Başka bir deyişle, öğretmenlerin okuldaki dedikodu ve söylentilerin etkileri boyutuna ilişkin görüşleri, mesleki kıdeme bağlı olarak anlamlı bir şekilde değişmektedir. Mesleki kıdem grupları arası farkların hangi gruplar arasında olduğunu bulmak amacıyla yapılan Scheffe testinin sonuçlarına göre; 6-10 yıl mesleki kıdem grubundaki öğretmenlerin okuldaki dedikodu ve söylentilerin etkileri boyutuna ilişkin (katılıyorum düzeyindeki) görüşlerinin, 21 ve daha fazla yıl mesleki kıdem grubundaki öğretmenlerin (kararsızım düzeyindeki) görüşlerinden daha yüksek olduğu belirlenmiştir.

Ayrıca; öğretmenlerin okuldaki dedikodu ve söylentilerin nedenleri boyutuna ilişkin görüşleri arasında mesleki kıdeme göre anlamlı bir fark olmadı̆̆ını göstermektedir, $F=2.58, p>.05$. Başka bir deyişle, öğretmenlerin okuldaki dedikodu ve söylentilerin nedenleri boyutuna ilişkin görüşleri, mesleki kıdeme bağlı olarak anlamlı bir şekilde değişmemektedir.

Araştırmanın yedinci alt problemi kapsamında; okul kademesi değişkenine göre öğretmenlerin okuldaki dedikodu ve söylenti durumu incelenmiştir. Okul kademesi değişkenine göre, öğretmenlerin okuldaki dedikodu ve söylenti durumuna ilişkin t-testi sonuçlarına aşağıdaki tabloda yer verilmiştir.

Tablo 10. Okul Kademesi Değişkenine Göre Öğretmenlerin Okuldaki Dedikodu ve Söylenti Durumuna İlişkin T-Testi Sonuçları

\begin{tabular}{llllllll}
\hline Boyutlar & Okul kademesi & $N$ & $\bar{x}$ & $S$ & $s d$ & $t$ & $p$ \\
\hline Dedikodu ve & İlkokul & 184 & 3.54 & .62 & 398 & .23 & .81 \\
söylentilerin nedenleri & Ortaokul & 216 & 3.53 & .68 & & & \\
\hline Dedikodu ve & İlkokul & 184 & 3.37 & .36 & 398 & .05 & .95 \\
söylentilerin etkileri & Ortaokul & 216 & 3.36 & .57 & & & \\
\hline Dedikodu ve & İlkokul & 184 & 3.44 & .39 & 398 & .17 & .86 \\
$\begin{array}{l}\text { söylentilerin etki ve } \\
\text { nedenleri (Genel) }\end{array}$ & Ortaokul & 216 & 3.43 & .53 & & & \\
\hline
\end{tabular}

" $p<.05$

Tablo incelendiğinde; öğretmenlerin okuldaki dedikodu ve söylenti durumuna ilişkin görüşleri, okul kademesine göre anlamlı bir farklılık göstermemektedir, $t(398)=.17, p>.05$. İlkokul ve ortaokulda görevli öğretmenlerin okuldaki dedikodu ve söylenti durumuna ilişkin görüşlerinin katılıyorum düzeyinde olduğu görülmektedir. Araştırma bulgusu, öğretmenlerin okuldaki dedikodu ve söylenti durumu ile okul kademesi arasında anlamlı bir ilişkinin olmadığ şeklinde de yorumlanabilir.

Tüm boyutlarda; öğretmenlerin okuldaki dedikodu ve söylentilerin neden $[t(398)=.23]$ ve etkileri $[t(398)=.05]$ boyutlarına ilişkin görüşleri, okul kademesine göre anlamlı bir farklılık göstermemektedir, $p>.05$.

\section{Sonuç ve Tartışma}

1. Araştırma sonucunda; öğretmenlerin, dedikodu ve söylenti durumuna ilişkin görüşlerinin katılıyorum düzeyinde olduğu görülmüştür. Bu durum, okullarda dedikodu ve söylenti mekanizmasının aktif ve yaygın bir biçimde işlediğini belirtebilir. 
Ayrıca boyutlar bazında dedikodu ve söylenti durumuna ilişkin görüşleri incelendiğinde ise; dedikodu ve söylentilerin nedenleri "katılıyorum" ve dedikodu ve söylentilerin etkilerinin ise "kararsızım" düzeyinde olduğu görülmüştür. Bu durum, okullarda yaşanan "fiziksel koşullardan ve çalışma ortamından memnuniyetsizlik, kurum içi resmî iletişim kanallarının yetersiz oluşu, kurum içinde hiyerarşinin fazla olması, çalışanların iş yüklerinin az olması, motivasyon sistemlerinin yetersizliği, temel eğitim (okul öncesi, ilkokul ve ortaokul) mevzuatından kaynaklanan atama, terfi, iş güvencesine ilişkin sorunlar ve kurumda yaşanan her türlü belirsizlik" gibi durumların yüksek düzeyde dedikodu ve söylentiye yol açtığını gösterebilir. Bunun yanı sıra, okullarda yaşanan orta düzeyde dedikodu ve söylentinin hem olumlu hem de olumsuz bir biçimde; "eğlenceli bir çalışma ortamı, çalışanların birbirine yakınlaşması, kişileri harekete geçirerek doğru bilgiye erişimin sağlanması, yönetici ve çalışanlar arasındaki güvenin azalması, gruplaşma, çalışanların moralinin bozulup stres yaratılması, iş verimliliği ve örgütsel bağllığın azalması, örgütün imaj ve itibarına zarar verilmesi, zarar ve değersizliğe yol açması" gibi etkilerinin olduğuna işaret edebilir.

Ayrıca öğretmenler tarafından okul içi (okul imajı, öğrenci tatmini, eğitim kalitesi ve "temel eğitim -okul öncesi, ilkokul ve ortaokul-" sistemi ve mevzuat ile ilgili) dedikodu ve söylenti konularının varlığı, okul dışı (yönetim, ücretler, öğretmenlerin özel hayatı, özlük değişikliği terfi, atama vb.- ve soruşturma, ceza vb. hakkında) dedikodu ve söylenti konularından daha fazla olarak görülmüştür. Bu durum, okullarda okul dişı durumlardan ziyade okul içi durumların daha fazla konuşulduğunu ve bu okul içi konuların dedikodu ve söylentiye daha çok dâhil edildiğini gösterebilir. Bu da, okullarda birtakım eğitim öğretim dışındaki konulara odaklanmaktan öte eğitim öğretim hakkındaki konuların yer edinmesini ve okulların etkililiğini sağlayabilir.

2. Araştırma sonucunda; öğretmenlerin okuldaki dedikodu ve söylenti durumuna ilişkin görüşleri, cinsiyete göre anlamlı bir farklılık göstermiştir. Kadın öğretmenlerin okuldaki dedikodu ve söylenti durumuna ilişkin görüşlerinin, erkek öğretmenlerin görüşlerinden yüksek olduğu görülmüştür. Bu durum, kadın öğretmenlerin okullarda dedikodu ve söylenti mekanizmasının aktif ve yaygın bir biçimde işlediğine dair daha yüksek bir görüşe sahip olduklarını belirtebilir. Bu da, kadın öğretmenlerin sosyal ağlar konusunda daha başarılı ve informel ilişki ve iletişim konularına önem ve ağırlık vermelerinden kaynaklanabilir.

Tüm boyutlarda; öğretmenlerin okuldaki dedikodu ve söylentilerin neden ve etkilerine ilişkin görüşleri, cinsiyete göre anlamlı bir farklılık göstermiştir. Kadın öğretmenlerin dedikodu ve söylenti neden ve etki boyutlarına ilişkin görüşlerinin, erkek öğretmenlerin görüşlerinden daha yüksek olduğu görülmüştür.

3. Araştırma sonucu; öğretmenlerin okuldaki dedikodu ve söylenti durumuna ilişkin görüşleri arasında yaşa göre anlamlı bir fark olduğunu göstermiştir. 21-30 ve 31-40 yaş grubundaki öğretmenlerin okuldaki dedikodu ve söylenti durumuna ilişkin görüşlerinin, 51 ve üzeri yaş grubundaki öğretmenlerin görüşlerinden daha yüksek olduğu belirlenmiştir. Bu durum, genç öğretmenlerin okullarda dedikodu ve söylenti mekanizmasının aktif ve yaygın bir biçimde işlediğine dair daha yüksek bir görüşe sahip olduklarını gösterebilir. Bu da, genç öğretmenlerin sosyal ağlar konusunda daha başarılı ve informel ilişki ve iletişim konularına önem ve ağırlık vermelerinden kaynaklanabilir.

Boyutlar bazında araştırma sonucu; öğretmenlerin okuldaki dedikodu ve söylentilerin nedenleri boyutuna ilişkin görüşleri arasında yaşa göre anlamlı bir fark olduğunu 
göstermiştir. 31-40 yaş grubundaki öğretmenlerin okuldaki dedikodu ve söylentilerin nedenleri boyutuna ilişkin görüşlerinin, 51 ve üzeri yaş grubundaki öğretmenlerin görüşlerinden daha yüksek olduğu belirlenmiştir.

Ayrıca; öğretmenlerin okuldaki dedikodu ve söylentilerin etkileri boyutuna ilişkin görüşleri arasında yaşa göre anlamlı bir fark olmadığını göstermiştir.

4. Araştırma sonucunda; öğretmenlerin okuldaki dedikodu ve söylenti durumuna ilişkin görüşleri, medeni duruma göre anlamlı bir farklılık göstermemiştir.

Tüm boyutlarda; öğretmenlerin okuldaki dedikodu ve söylentilerin neden ve etkileri boyutlarına ilişkin görüşleri, medeni duruma göre anlamlı bir farklılık göstermemiştir.

5. Araştırma sonucu; öğretmenlerin okuldaki dedikodu ve söylenti durumuna ilişkin görüşleri arasında öğrenim durumuna göre anlamlı bir fark olmadığını göstermiştir.

Boyutlar bazında araştırma sonucu; öğretmenlerin okuldaki dedikodu ve söylentilerin neden ve etkileri boyutlarına ilişkin görüşleri arasında öğrenim durumuna göre anlamlı bir fark olmadığını göstermiştir.

6. Araştırma sonucu; öğretmenlerin okuldaki dedikodu ve söylenti durumuna ilişkin görüşleri arasında mesleki kıdeme göre anlamlı bir fark olduğunu göstermiştir. 6-10 yıl mesleki kıdem grubundaki öğretmenlerin okuldaki dedikodu ve söylenti durumuna ilişkin görüşlerinin, 21 ve daha fazla yıl mesleki kıdem grubundaki öğretmenlerin görüşlerinden daha yüksek olduğu belirlenmiştir. Bu durum, mesleki hayatının başındaki öğretmenlerin okullarda dedikodu ve söylenti mekanizmasının aktif ve yaygın bir biçimde işlediğine dair daha yüksek bir görüşe sahip olduklarını belirtebilir.. Bu da, mesleki hayatının başındaki öğretmenlerin sosyal ağlar konusunda daha başarılı ve informel ilişki ve iletişim konularına önem ve ağırlık vermelerinden kaynaklanabilir.

Boyutlar bazında araştırma sonucu; öğretmenlerin okuldaki dedikodu ve söylentilerin etkileri boyutuna ilişkin görüşleri arasında mesleki kıdeme göre anlamlı bir fark olduğunu göstermiştir. 6-10 yıl mesleki kıdem grubundaki öğretmenlerin okuldaki dedikodu ve söylentilerin etkileri boyutuna ilişkin görüşlerinin, 21 ve daha fazla yıl mesleki kıdem grubundaki öğretmenlerin görüşlerinden daha yüksek olduğu belirlenmiştir.

Ayrıca; öğretmenlerin okuldaki dedikodu ve söylentilerin nedenleri boyutuna ilişkin görüşleri arasında mesleki kıdeme göre anlamlı bir fark olmadığını göstermiştir.

7. Araştırma sonucunda; öğretmenlerin okuldaki dedikodu ve söylenti durumuna ilişkin görüşleri, okul kademesine göre anlamlı bir farklılık göstermemiştir.

Tüm boyutlarda; öğretmenlerin okuldaki dedikodu ve söylentilerin neden ve etkileri boyutlarına ilişkin görüşleri, okul kademesine göre anlamlı bir farklılık göstermemiştir.

\section{Öneriler}

1. Tüm okul paydaşlarının sağlıklı etkileşim ve iletişimlerinin sosyal etkinliklerle sağlanması yoluyla okullarda dedikodu ve söylenti mekanizmasının olumlu etkilerinden faydalanabilecek okul atmosferleri oluşturulabilir. 
2. Üniversitelerin işbirliğiyle gerçekleştirilecek kişisel ve örgütsel bazdaki birtakım eğitimler yoluyla okullardaki dedikodu ve söylenti mekanizmasının olumsuz etkileri azaltılabilir.

3. Başta erkek, ileri yaşlardaki ve tecrübeli öğretmenler olmak üzere tüm öğretmen ve yöneticilere sosyal ağlar, informel ilişki ve iletişim konularında birtakım eğitimler düzenlenebilir.

4. Bu araştırma, okullarda dedikodu ve söylenti mekanizmasının işleyişini incelemiştir. Benzer araştırmalar, diğer kamu ve özel sektör çalışanları bağlamında da gerçekleştirilebilir.

5. Bu araştırmada, okullarda dedikodu ve söylenti mekanizmasının işleyişinin belirlenmesine dönük olarak nicel yöntemden yararlanılmıştır. Benzer araştırmalar; nitel veya karma yöntemler kullanılarak da yapılabilir.

\section{KAYNAKÇA}

Akande, A., \& Odewale, F. (1994). One more time: How to stop company rumours. Leadership and Organization Development Journal, 15(4), 27-30.

Büyüköztürk, Ş. (2013). Sosyal bilimler için veri analizi el kitabı. Ankara: Pegem.

De Gouveia, C. M., Van Vuuren, L. J., \& Crafford, A. (2005). Towards a typology of gosspip in the workplace. SA Journal of Human Resources Management 3(2), 56-68.

DiFonzo, N., \& Bordia, P. (1997). Rumor and prediction: Making sense (but losing dollars) in the stock market. Organizational Behavior and Human Decision Processes, 71(3), 329-353.

DiFonzo, N., \& Bordia, P. (2002). Corporate rumor activity, belief and accuracy. Public Relations Review, 1-18, 500.

DiFonzo, N., Bordia, P., \& Rosnow, R. L. (1994). Reining in rumors. Organizational Dynamics, 23(1), 47-62.

Dodig-Crnkovic, G., \& Anokhina, M. (2008). Workplace gossip and rumor: The information ethics perspective. In Proceedings of the Tenth International Conference ETHICOMP.

Erol, Y., \& Akyüz, M. (2015). Dünyanın en eski medyası: Dedikodunun örgüt düzeyindeki işlevleri ve algılanışı: Sağlık örgütlerinde bir alan araştırması. Journal of World of Turks, $7(2), 149-166$.

Eşkin, F. ( 2010). Dedikodu ve söylenti: Ölçek geliştirme çalışması ve hemşirelikte bir uygulama. Yüksek Lisans Tezi, İstanbul Üniversitesi Sağlık Bilimleri Enstitüsü, İstanbul.

Eşkin Bacaksız, F., \& Yıldırım, A. (2013). Dedikodu ve söylenti tutumu ölçeği'nin geliştirilmesi. Anadolu Hemşirelik ve Sağlık Bilimleri Dergisi, 16(1), 36-42.

Houmanfar, R., \& Johnson, R. (2004). Organizational implications of gossip and rumor. Jounral of Organizational Behavior Management, 23(2-3), 117-138.

Kapferer, J. N. (1992). Oynak bir fenomen. Dedikodu ve söylenti: Dünyanın en eski medyası. Çev. Işın Gürbüz, İstanbul: İletişim.

Karasar, N. (2015). Bilimsel araştırma yöntemi: kavramlar, ilkeler, teknikler. Ankara: Nobel.

Knapp, R. H. (1944). A psychology of rumor. Public Opinion Quarterly, 8(1), 22-37. 
Kurland, N. B., \& Pelled, L. H. (2000). Passing the word: Toward a model of gossip and power in the workplace. Academy of Management Review, 25(2), s.428-438.

Leblebici, N. D., Yıldız, H. H., \& Karasoy, A. (2009). Örgütsel yaşamda dedikodunun araçsallığ 1 ve algılanışı. S.Ü. İ.I.B.F. Sosyal ve Ekonomik Araştırmalar Dergisi, 561-574.

MEB (2018). 2017-2018 öğretim yılı eğitim istatistikleri. http://ankara.meb.gov.tr/www/egitimistatistikleri/icerik/24 sayfasından erişilmiştir.

Michelson, G., \& Mouly, V. S. (2002). 'You didn't hear it from us but...': Towards an understanding of rumour and gossip in organisations. Australian Journal of Management, 27(Special Issue), 57-65.

Michelson, G., \& Mouly, V. S. (2004). Do loose lips sink ships? The meaning, antecedents and consequences of rumour and gossip in organisations. Corporate Communications: $A n$ International Journal, 9(3), 189-201.

Michelson, G., Van Iterson, A., \& Waddington, K. (2010). Gossip in organizations: Contexts, consequences and controversies. Groups \& Organization Management 35(4), 371-390.

Mishra, J. (1990). Managing the grapevine. Public Personnel Management, 19(2), 213-228.

Noon, M., \& Delbridge, R. (1993). News from behind my hand: Gossip in organizations. Organization Studies, 14(1), 23-36.

Özşarlak, P. (2016). Örgütlerde dedikodu ve söylentilerin ortaya çıkış nedenleri, içerikleri ve etkilerine ilişkin çalışan algılarının değerlendirilmesi ve bir uygulama örneği. Yüksek Lisans Tezi, Yaşar Üniversitesi Sosyal Bilimler Enstitüsü, İzmir.

Robbins, S. P., \& Judge, T. A. (2014). Essentials of organizational behavior (Twelfth Edition). New Jersey: Pearson.

Rosnow, R. L. (2001). Rumor and gossip in interpersonal interaction and beyond: A social exchange perspective. In R. M. Kowalski (Ed.), Behaving Badly: Aversive Behaviors in Interpersonal Relationships (pp. 203-232). Washington, DC: American Psychological Association.

Solmaz, B. (2004). Söylenti ve dedikodu kavramı. Kurumsal söylenti ve dedikodu, Türkiye'deki işletmeler üzerine bir uygulama. Konya: Tablet. 